treatment for minimal change nephrotic syndrome. Arch Dis Child 1986;61:153-8.

2 Tanphaichitr P, Tanphaichitr D, Sureertanan J, Chatasingh S. Treatment of nephrotic syndrome with levamisole. J Pediatr 1980;96:490-3.

3 Aune TM. Inhibition of interferon or soluble immune response suppressor mediated suppression by levamisole. Int J Immunopharmacol 1983;5:91-8.

${ }^{4}$ Hersey $\mathrm{KH}$, Werkmeister U, Abele U. Inhibition of $\mathrm{T}$ cells in pokeweed mitogen-stimulated cultures of $T$ and $B$ cells by levamisole in vitro and in vivo. Clin Exp Immunol 1981;46: $340-5$.

P F W Miller St Mary's Hospital, Manchester

\section{Chemoprophylaxis of meningitis}

Sir,

I found the article by Dr Hillas Smith on 'Chemoprophylaxis of meningitis' both interesting and informative. ${ }^{1}$

I was, however, a little puzzled by the statement in paragraph three, "A case can be made for routine chemoprophylaxis in patients before discharge from hospital when curative treatment of meningococcal or influenzal meningitis is completed'. In the previous paragraph you say, 'but it should be pointed out that penicillin, which is so effective in treatment of cases, does not prevent carriage or indeed the development of invasive disease when it is used prophylactically'.

Are you suggesting that even after aggressive intravenous treatment with big doses of penicillin or ampicillin, the patient remains a carrier and needs chemoprophylaxis on discharge from hospital? If this is so, we might all have to change our present policy regarding the duration of barrier nursing of meningitis.

\section{Reference}

${ }^{1}$ Smith H. Chemoprophylaxis of meningitis. Arch Dis Child 1986;61:4-5.

\section{G RaJan Staincliffe General Hospital, Dewsbury WF13 $4 H S$, England}

Dr Hillas Smith comments:

Dr Rajan is quite correct in suggesting that even after appropriate curative treatment some patients may still harbour the infective organism in the nasopharynx. Because of this, the idea has grown up that treated patients may well require eradication with a drug such as rifampicin. An alternative course would be for routine cultures to be taken at the end of treatment and to await positive results before embarking on rifampicin chemoprophylaxis.

\section{Medical evidence in child abuse}

Sir,

I read with interest the article by Drs Taitz and King. ${ }^{1}$ The outcome of child abuse certainly depends on the input. Paediatrics has probably failed to define at least one of the input characteristics of abuse cases sharply enough.

The paediatrician gains increasing experience of the medical aspects of the many forms of child abuse during training. Training makes little attempt, however, to provide insight into the legal aspects of abuse proceedings. Though the junior doctor may on his own initiative try to gain some knowledge of law, all too often he is left to discover the rules of the legal game the hard way by sustaining one or more 'batterings' at the hands of our legal contemporaries in court. Lack of experience in procedure may not only be embarrassing to the individual concerned but may also fail to serve the interests of the child by slowing (or even halting) the court process and by making the paediatrician appear more ignorant than he really is.

More senior expert witnesses will have developed legal nous over the years. Sometimes, junior staff have to appear in abuse cases, ranging from the trivial to manslaughter. They are unlikely to have much or indeed any legal experience. Some attempt to remedy this could be made by liaison with the legal profession to include some preparation for such cases in training. This would help to prevent some of the legal stumbling blocks that may add to the already difficult and unpleasant business of abuse cases.

\section{Reference \\ 1 Taitz LS, King J. Medical evidence in child abuse. Arch Dis Child 1986;61:205-6.}

A L Evans

Department of Physiology, Middlesex Hospital Medical School, London W1P $6 D B$

Dr Taitz comments:

I agree that most doctors are inadequately trained to handle cross examination in court. Often, too, they seem to have insufficient grasp of the evidence they are presenting. How to correct these deficiencies represents a serious challenge to medical educators.

\section{Vancomycin and necrotising enterocolitis}

Sir,

During recent months we have been trying to prevent necrotising enterocolitis in intensive care babies by giving a two day course of oral vancomycin before introducing oral feeds. We have also used oral vancomycin in addition to metronidazole and other systemic antibiotics in the treatment of necrotising enterocolitis. We are not as yet in a position to say whether this has been a helpful treatment, but we have been concerned to establish that it is not a harmful one in terms of aminoglycoside toxicity. There is evidence for absorption of orally administered vancomycin in adults with enterocolitis, ${ }^{12}$ and we felt that the 